\title{
The Carbon sink Decreasing in the Eastern Ghats's of Andhra Pradesh in India
}

\author{
Ravi Gedela
}

Department of Bio-Sciences, Rajiv Gandhi University of Knowledge Technologies (RGUKT), India.

\begin{abstract}
The carbon sink in the Eastern Ghats of Andhra Pradesh (India) showed decreasing order through the process of deforestation during 2004-2014 and outlook in the coming 2005-2025 years $\approx-6.896 \times 10^{25} \mu \mathrm{mol} \mathrm{m} \mathrm{s}^{-2}$ and $5.648 \times 10^{25} \mu \mathrm{mol} \mathrm{m} \mathrm{m}^{-2}$ respectively (i.e. lesser amount of photosynthesis reactions are taking place). The carbon sinks are immensely increasing in the process of afforestation during 2004-2014 and upcoming 2005-2025 years, showed an analysis $\approx 4.743 \times 10^{25} \mu \mathrm{mol} \mathrm{m} \mathrm{m}^{-2}$ and $\approx$ $5.217 \times 10^{25} \mu \mathrm{mol} \mathrm{m}^{-2} \mathrm{~s}^{-1}$ respectively (more amount of photosynthesis reaction is taking place). The decreasing and increasing carbon sink phenomenon (combine effect of negative change: deforestation, forest firing, mining and positive change: Afforestation), through the process of deforestation and afforestation during 2004-2014 and viewpoint until 2025 years, showed an analysis of respective values $\approx-2.435 \times 10^{25} \mu \mathrm{mol} \mathrm{m}^{-2} \mathrm{~s}^{-1}$ and $\approx$ $4.696 \times 10^{25} \mu \mathrm{mol} \mathrm{m} \mathrm{m}^{-2} \mathrm{~s}^{-1}$. The Carbon sinks are in neutral condition during 2004-2014 and forthcoming 2025 years either deforestation or Aforestation, showed an analysis of value $\approx 4.269 \times 10^{25} \mu \mathrm{mol} \mathrm{m} \mathrm{m}^{-1}$ remains constant. Forest is the key principle machinery for the synthesis of Carbohydrates $\left[\left(\mathrm{CH}_{2} \mathrm{O}\right) n\right]$ in the presence of $\mathrm{CO}_{2}, \mathrm{H}_{2} \mathrm{O}$ and sunlight and photosynthesis. The human activities which are affecting majorly to the Carbon sink in Eastern Ghat's of Andhra Pradesh in India, especially shifting of tribal's cultivation and forest firing leads to catastrophic effects.
\end{abstract}

Keywords- $\mathrm{CO}_{2}$, Carbon sink, In-situ conservation, deforestation, shifting of cultivation.

\section{INTRODUCTION}

A carbon sink is a natural phenomenon, the carbon which accumulates and stores in a chemical compound cellulose in the leaves of plant system in an environment. Forest is the key principle machinery for the synthesis of Carbohydrates $\left[\left(\mathrm{CH}_{2} \mathrm{O}\right) n\right]$, in the mechanism of photosynthesis, and utilization of $\mathrm{CO}_{2}, \mathrm{H}_{2} \mathrm{O}$ and sunlight. The $\mathrm{CO}_{2}$ concentration in the atmosphere had increased by $31 \%$ since the beginning of the industrial era, from 280 to $360 \mathrm{ppm}$ (IPCC, 2001). The Anthropogenic emissions of $\mathrm{CO}_{2}$ originate primarily from the burning of fossil fuels and forest firing in the tropical regions. However, this flow had already began more than a century ago with the industrial revolution, continues to grow, and is sufficient to explain global warming and the resulting imbalance in the climate system (Cox et al., 2000). The emissions of $\mathrm{CO}_{2}$ significantly increasing in $21^{\text {st }}$ century and $\mathrm{CO}_{2}$ concentration in the atmosphere reaches to $980 \mathrm{ppm}$, the average increase of ground temperature reaches to 8 (5.5_ globally), and the earth's biosphere emits $170 \mathrm{GtC}$ (Cox et al., 2000). There are still questions regarding the long-term future of the biospheres carbon pool, some of the $\mathrm{CO}_{2}$ emissions (on the order of $6 \mathrm{GtC} /$ year) are reabsorbed by the terrestrial and oceanic ecosystems. There are several other bio-climatic models indicate that the ecosystems absorption capacity is approaching its upper limit and should diminish in the future, possibly even reversing direction within 50 to 150 years, as forests becoming a net source of $\mathrm{CO}_{2}$. Indeed, global warming could cause an increase in heterotrophic respiration and the decomposition of organic matter, and a simultaneous decrease of the carbon sink's effectiveness, thereby transforming the forestry ecosystems into a net source of $\mathrm{CO}_{2}$ (Scholes, 1999). Many studies have provided the estimation on the carbon stock changes for Forest Management or for the total forest area at both local and multi-national scales (Mund et al. 2002, Masera et al. 2003), national (Karjalainen et al. 2002, Stinson et al. 2011, Pilli et al. 2013) (Bottcher et al. 2012, Thuille et al. 2000, Masera et al. 2003, Hoogmoed et al. 2012).

The Role of Forests in Carbon Sink

Forest ecosystems play a crucial role in global carbon cycling which is acting as sink and source. Forests form an active carbon pool that accounts for $60 \%$ of carbon storage on the earth's land surface (Wilson \& Daff 2003). Tropical forests dominate the role of forests in the global carbon flux and stocks, and therefore it requires researchers and policy makers to estimate the carbon sequestration potentials (Dixon et al.1994). Protecting carbon stocks in the existing forest vegetation have become more important to mitigate the increasing carbon dioxide concentration in the atmosphere (Lal, 2005). Stomata crucially permit plants to 
regulate transpiration of water loss from leaves during the simultaneous uptakes of $\mathrm{CO}_{2}$ for photosynthesis (Farquhar and Sharkey 1982, Hetherington and Woodward 2003). The oxidation of carbon found in organic matter and the subsequent emissions of $\mathrm{CO}_{2}$ result from the following processes: respiration of living biomass, decomposition of organic matter by other living organisms, and combustion (fires) (IPCC, 2000).

Unprecedented anthropogenic activities have been increasing since globalization. Subsequently industrialization and urbanization have reportedly lead to a corresponding decline and degradation of tropical forest ecosystems of the world (Eraldo et al. 2010; Mingxia et al. 2010, Vaidyanathana et al. 2010). Many authors concluded for the recent period that, the Indian forests are nationally a small source with some regions acting as small sinks of carbon (Ravindranath, et al.1997; Haripriya, 2003; Chhabra and Dadhwal, 2004; Ravindranath, et al., 2008). The improved quantification of pools and fluxes related to the forest carbon cycle is important for understanding the contribution of India's forests to net carbon emissions as well as their potentiality for carbon sequestration in the context of the Kyoto Protocol (Chhabra and Dadhwal, 2004). In India, $\mathrm{CO}_{2}$ emissions from forest diversion or loss are largely offset by carbon uptake due to forest increment and afforestation.

The shifting of cultivation is practiced by tribal people for cultivating paddy, buck wheat, maize, millets, tobacco, and banana. And there are the most grown on the burnt over clearings and the products shared jointly by the clan. The shifting of cultivation in India is known as jhum in Assam, punam krishi is Kerala, podu in Andhra Pradesh and Orissa, bewar, mashan, penda and beera in different parts of Madhya Pradesh. About 20 lakh hectares of forests are cleared every year by falling or burning the trees and shrubs (Indian Geography). The purpose of this study is to figure out the improved estimates for gain and loss of biomass during years of time span. The Eastern Ghats region like Srikakulam, Vizayanagaram and Visakhapatnam are the major places which are occupied as much as $5.5 \%$ by Tribal population in Andhra Pradesh, India (2015); their habitats completely depend on forest based and agricultural cultivation. it is method called shifting of cultivation (Fig 1: A, B and C). In this process, the persisting existence of habitation is leading to deforestation, decreases rain fall, and crisis of in-situ conservation.

\section{MATERIALS AND METHODS}

\section{Description of the Case Studies:}

The analysis focused on forest zone Eastern Ghats region of Srikakulam, Vizayanagaram and Visakhapatnam districts in www.ijeab.com
Andhra Pradesh, India. In the total population of 50 million, percentage of tribal's population was $5.5 \%$ in Andhra Pradesh, India (census data, 2015). Those above mentions places are selected areas for studies, because of their habitants who are completely forest base rural economy and their agricultural cultivations were of shifting cultivation (Fig 1: A, B and C). In this cultivation method, the persisting existence of habitation leads to deforestation which decreases average rain fall, and increases the crisis for in-situ conservation.

The Parameter Considered in MATLAB Programme for Carbon Sink Analysis:

Photosynthesis reaction, synthesis of carbohydrates $\left[\left(\mathrm{CH}_{2} \mathrm{O}\right) \mathrm{n}\right]$ in the presence of $\mathrm{CO}_{2}, \mathrm{H}_{2} \mathrm{O}$ and sunlight : $\mathrm{nCO}_{2}+\mathrm{nH}_{2} \mathrm{O}------>\left[\mathrm{CH}_{\mathrm{n}} \mathrm{O}\right] \mathrm{n}+\mathrm{nO}_{2}$.

The number of hectors $(\mathrm{H})$, trees per hector $(\mathrm{Ht})$, leafs per tree $(\mathrm{Htl})$, cells per leaf(Htlc), enzymes per cell(Htlce), the time $(\mathrm{sec})$ taken to complete the photosynthesis $(\mathrm{t})$, the number of years and the starting year. $\mathrm{H}=$ input('enter the no of hectors $(\mathrm{H})=$ ');

$\mathrm{Ht}=$ input('enter the no of trees per hector $(\mathrm{Ht})=$ ');

$\mathrm{Htl}=$ input('enter the no of leafs per tree $(\mathrm{Htl})=$ ');

Htlc=input('enter the no of cells per leaf $(\mathrm{Htlc})=$ ');

Htlce=input('enter the no of enzymes per cell(Htlce)= '); $\mathrm{t}=$ input('enter the time(sec) taken to complete the photosynthesis $(\mathrm{t})=$ ');

year=input('enter the no of years $=$ ');

$\mathrm{y}=$ year;

year_start=input('enter the starting year $=$ ');

$\mathrm{pn} \_\mathrm{y}=(31536000) /(\mathrm{t}) ; \%$ pn_y is the no of photo synthesis reactions per year in an enzyme

\%for $\mathrm{j}=1: 3$

$\mathrm{I}=$ input('enter the percentage of deforestation (or)

aforestation $(\mathrm{I})=$ ');

for $\mathrm{i}=1: \mathrm{y}$

$\mathrm{n}=\mathrm{Htlce} * \mathrm{Htlc}^{*} \mathrm{Htl} * \mathrm{Ht} *(1+(\mathrm{I} * \mathrm{i})) * \mathrm{H} ; \%$ 'n' is a no of enzymes in a hector

pn_total $(1)=0$;

$\operatorname{Time}(1)=0$;

pn_total $(\mathrm{i}+1)=\mathrm{pn} \_\mathrm{y}^{*} \mathrm{n}$;

Time $(i+1)=i+y e a r \_s t a r t-1$;

end

plot(Time $\left.(2: \mathrm{y}+1), \mathrm{pn} \_t \operatorname{total}(2: \mathrm{y}+1)\right)$

title('Years Vs Photosynthesis in Aforestation')

xlabel('Years')

ylabel('no of Photosynthesis')

$\%$ grid on

\section{RESULTS AND DISUCUSSION}

The studies on carbon sink in Eastern Ghats region of Andhra Pradesh in India, have evaluated results showed

Page | 719 
Carbon sink decreasing order during 2004-2014 through the process of tribal people shifting of cultivation leads to deforestation (Fig.1:A, B and C), showed the analysis of values $\approx-6.898 \times 10^{25} \mu \mathrm{mol} \mathrm{m} \mathrm{m}^{-2} \mathrm{~s}^{-1}$ (MATLAB programme) (Fig.2.1). In an outlook of coming 2025 year, the evaluated results showed the Carbon sink decreasing order through the methods of deforestation, showed an analysis of values $\approx$ $-5.648 \times 10^{25} \mu \mathrm{mol} \mathrm{m} \mathrm{m}^{-2} \mathrm{~s}^{-1}$ (Fig.3.1). The Carbon sinks increasing order in a methods of aforestation since 20042014 and 2005-2025, showed an analysis of values $\approx 4.135 \mathrm{x}$ $10^{25} \mu \mathrm{mol} \mathrm{m} \mathrm{s}^{-1}$ (Fig.2.2) and $\approx 5.002 \times 10^{25} \mu \mathrm{mol} \mathrm{m} \mathrm{s}^{-2}$ ${ }^{1}$ (Fig.3.2) respectively (i.e more amount of Photosynthesis reaction is taking place). The carbon sink has been decreasing since 2004 and roughly estimates that it will continue to happen till the year 2025 at both effect of negative changes and positive changes (negative change: deforestation, shifting of cultivation and forest fire; positive change: Aforestation), showed an analysis of values $\approx$ $2.435 \times 10^{25} \mu \mathrm{mol} \mathrm{m}^{-2} \mathrm{~s}^{-1}$ (Fig.2.3) and $\approx-4.696 \times 10^{25} \mu \mathrm{mol} \mathrm{m}-$ ${ }^{2} \mathrm{~s}^{-1}$ (Fig.3.3) respectively (i.e. reduced amount of Photosynthesis reaction taking place).

Carbon sinks at neutral condition is constant since 20042014 and 2005-2025 either deforestation or Afforestation, showed an analysis of values $\approx 4.269 \times 10^{25} \mu \mathrm{mol} \mathrm{m} \mathrm{m}^{-2} \mathrm{~s}^{-}$

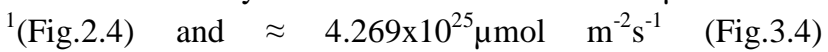
respectively. This type of phenomenon wouldn't support in natural system in entire globe, people could involve either deforestation or Afforestation, but it can't be in a constant state. The anthropogenic activities of deforestation, that leads to Carbon sink decreasing in the Eastern Ghat's of Andhra Pradesh in India, especially tribal people shifting of cultivation as a catastrophic effect (Fig.1: A, B and C).

\section{DISCUSSION}

Carbon sink at forest for biomass production is playing a major role, first one is the photosynthesis mechanism i.e. $\mathrm{CO}_{2}$ (converted into carbohydrate) and second one is plant transpiration to release water $\left[\mathrm{H}_{2} \mathrm{O}\right]$ moisture in the atmospheres, which is mixing up the $\mathrm{CO}_{2}$ appearance as a Carbonic acid $\left[\mathrm{H}_{2} \mathrm{CO}_{3}\right]$. These two processes are mainly involve to maintaining balance of atmospheric $\mathrm{CO}_{2}$, for the function of Carbon sink in the forest, similar process continue to happen in the ocean as well, for the surviving of ocean biomasses. The role of forests in climate changes, the vegetation, living plant biomass consisting of wood and non-wood materials (IPCC, 2000), absorb polluted molecule and enhance the Carbon sink. The dead wood and litter biomass, made up of plant debris is an important source of nutrients for plant growth (IPCC, 2000).

The evaluation of data and approach to conserving the natural heritage as per Government of India Ministry of www.ijeab.com
Environment \& Forest Policy Division,2012; to maintain the environmental stability through preservation and, where ever necessary, restoration of the ecological balance that has been adversely disturbed by serious depletion of the forests of the country. The vast variety of flora and fauna, which represent the remarkable biological diversity and genetic resources of the country are increasing sustainability the forest/tree cover in the country through massive afforestation methods. The requirements of fuel wood, fodder, minor forests produce small timber for the rural and tribal populations and increasing the productivity of forests to meet essential national needs as well to encouraging efficient utilization.

The contribution to climate change mitigation depends on the size and permanence of the carbon pool, and on the fuel wood increment. Increasing the energy efficiency of fuel wood usage and derived products as well improving and adapting stoves is necessary in order to raise energy efficiency and to avoid the over-exploitation of certain species which have low wood density and they burn rapidly.

\section{CONCLUSION}

Biogeochemical cycle of carbon had greatly affected in the Eastern Ghats of Andhra Pradesh, India. The result suggest that, afforestation increases carbon sinks, through the method of planting new forests, rehabilitating the degraded forests and enriching the existing forests in order to contribute to mitigating climate change. These actions increase the rate and quantity of carbon sequestration of biomass in the forest. The carbon reservoir in the forest biomass and soils are very large, highlighting the importance of conserving natural forest, and eliminating agricultural practices which contribute to the deterioration of these reservoirs. One aspect of the debate about carbon sinks are, whether conservation activities should be accounted or not. These activities aim to protect a forest area threatened by human-induced deforestation, particularly from farming. Climate specialists consider this conservation option to be the "best strategy for sink maintenance" (Valentini et al., 2000) to the extent that it contributes more effectively to carbon storage and preserves the biodiversity associated with old-growth forests.

National and provincial governments of department of forest can take some steps in this direction, such as: (i) pass acts for the conservation of forests, (ii) survey of the forest resources, (iii) categorization of forest areas and proper delimitation of reserved forest areas, (iv) find out the areas where reforestation can be done, (v) regulate the commercial use of forest products, (vi) protect forest from fire, mining and other natural calamities, (vii) develop national parks, (viii) encourage forests developmental

Page | 720 
activities like social forestry, agro-forestry, etc., and (ix) prepare master plans, both for long-term and short-term period, etc.

The government has to take steps for awareness and educating the tribal people on shifting of cultivation and forest firing; and has to propose new methods for replacing of shifting of cultivation and promoting biodiversity. The deforestation should be prohibited, wastage of timber and fuel wood to be avoided, alternative sources of energy, such as biogas should be used to supplement fuel wood, forest fires should be prevented, pests and diseases of the forest trees should be controlled chemically and biologically, grazing of cattle in forests should be discouraged, reforestation of the deforested areas should be undertaken, forestation at larger areas should be done in the areas which are unfit for agriculture and should adopt new forest management techniques.

\section{ACKNOWLEDGEMENT}

I am obliged to the Dept of Forest, for providing Forest data online; Mr. Appala Naidu, who helped me to take Photos of Eastern Ghats region in the Seethampeta, Srikakulam dst., Andhra Pradesh. I extend my sincere gratitude to Mr. Naidu Babu, Lecturer in the Dept. of Mechanical Engineering, RGUKT IIIT, Nuzvid on MATLAB Programme, and Dr. Rajesh Dept of English for English assistance.

\section{REFERENCES}

[1] Allen SE, Grimshaw HM, Rowland AP .1986. Chemical analysis. In: "Methods in plant ecology" (Moore PD, Chapman SB eds). Blackwell Scientific Publications, London, UK, pp. 285-344.

[2] Atjay GL, Ketner P, Duvignead P .1979. Terrestrial primary production and phytomass. In: "The global carbon cycle" (Bolin B, Degens ET,Kempe S eds). Wiley and Sons, New York, USA, pp. 129-182.

[3] Baishya R, Barik Sk, Upadhaya K .2009. Distribution pattern of aboveground biomass in natural and plantation forests of humid tropics in northeast India. Tropical Ecology 50: 295-304.

[4] Bell G, Kerr A, McNickle D, Woollons R .1996. Accuracy of the line intersect method of postthinning sampling under orientation bias. Forest Ecology and Management 84: 23-28.

[5] Böttcher H, Verkerk PJ, Mykola G, Havlik P, Grassi G .2012. Projection of the future EU forest CO2 sink as affected by recent bioenergy policies using two advanced forest management models. GCB Bioenergy 4 (6): $773-783$.
[6] Brown S, Lugo AE .1982. The storage and production of organic matter in tropical forests and their role in the global carbon cycle. Biotropica 14: 161-187.

[7] Canadell JG, Raupach MR, Houghton RA .2009. Anthropogenic $\mathrm{CO} 2$ emissions in Africa. Biogeosciences 6: 463-468.

[8] Cannell MGR, Milne R .1995. Carbon pools and sequestration in forest ecosystems. Forestry 68: 361378.

[9] Cox . 2000. Acceleration of global warming due to carbon-cycles

a. feedback in a coupled climate model. Nature, 408.

[10]Dixon RK, Brown S, Solomon RA, Trexler MC, Wisniewski J .1994. Carbon pools and flux of global forest ecosystems. Science 263: 185-190.

[11]Eraldo ATM, David LS, Marcos AP, Walter C, Luis CF .2010. Assessment of tropical forest degradation by selective logging and fire using Landsat imagery. Remote Sensing of Environment 114: 1117-1129.

[12]Farquhar Gd, Sharkey TD .1982. Stomatal conductance and Photosynthesis. Annu Rev Plant Physiol 33:17-47

[13] Hashimotio T, Kojim K, Tange T, Sasaki S .2000. Changes in carbon storage in fallow forests in the tropical lowlands of Borneo. Forest Ecology and Management 3: 31-337.

[14] Hetherrington AM, Woodward FI .2003. The role of stomata in sensing and driving environmental change. Nature 424:901-908.

[15] Hoogmoed M, Cunningham S, Thomson J, Baker P, Beringer J, Cavagnaro T .2012. Does afforestation of pastures increase sequestration of soil carbon in Mediterranean climates? Agriculture, Ecosystems and Environment 159: 176- 183.

[16] Houghton RA, Goodale C .2004. Effects of landuse change on the carbon balance of terrestrial ecosystems. Geophysical Monograph Series 153: 85-98.

[17] Houghton RA .2005. Aboveground Forest Biomass and the Global Carbon Balance. Global Change Biology 11: 945-958.

[18] IPCC .2003. Good practice guidance for land use, land-use change and forestry (Penman J, Gytarsky M, Hiraishi T, Krug T, Kruger D, Pipatti R, Buendia L, Miwa K, Ngara T, Tanabe K, Wagner F eds). Institute for Global Environmental Strategies, Hayama, Japan, pp. 3.1-3.272.

[19] IPCC .2006. Guidelines for national greenhouse gas inventories (vol. 4). Agricolture, forestry and other land use (Eggleston S, Buendia L, Miwa K, Ngara T, 
Tanabe $\mathrm{K}$ eds). Institute for Global Environmental Strategies, Hayama, Japan, pp. 4.1-4.83.

[20] IPCC .2013. Revised supplementary methods and good practice guidance arising from the Kyoto protocol (Hiraishi T, Krug T, Tanabe K, Srivastava N, Jamsranjav B, Fukuda M, Troxler T eds). Institute for Global Environmental Strategies, Hayama, Japan, pp. 268.

[21] Jana BK, Biswas S, Majumder M, Roy PK, Maunder A .2009. Carbon sequestration rate and aboveground biomass carbon potential of four young species. Journal of Ecology and Natural Environment 1: 15-24.

[22] Jeong JH, Kim C, Lee WK .1998. Soil organic carbon content in forest soils of Korea. Forest Research Institute Journal of Forest Science 57:178-183.

[23] Karjalainen T, Pussinen A, Liski J, Nabuurs GJ, Erhard M, Eggers T et al. 2002. An approach towards an estimate of the impact of forest management and climate change on the European forest sector carbon budget: Germany as a case study. Forest Ecology and Management 162 (1): 87-103.

[24]Lal R .2005. Forest soils and carbon sequestration. Forest Ecol Manag 220: 242-258.

[25] Marchetti M, Bertani R, Corona P, Valentini R .2012. Changes of forest coverage and land uses as assessed by the inventory of land uses in Italy. Forest 9 (4): 170-184. [in Italian with English abstract]

[26] Masera OR, Garza-Caligaris JF, Kanninen M, Karjalainen T, Liski J, Nabuurs GJ et al.2003. Modelling carbon sequestration in afforestation, agroforestry and forest management projects: the CO2- FIX V. 2 approach. Ecological Modelling 164 (2-3): 177-199.

[27] Mund M, Kummetz E, Hein M, Bauer GA, Schulze ED .2002. Growth and carbon stocks of a spruce forest chronosequence in central Europe. Forest Ecology and Management 171 (3): 275-296.

[28] Mingxia Z, John RF, Xuelong J, Wei W, Bosco PLC, Guopeng R et al . 2010. Degradation of tropical forest in Hainan, China, 1991-2008: Conservation implications for Hainan Gibbon (Nomascus hainanus). Biological Conservation 143: 1397-1404.

[29] Natha AJ, Das G, Das AK .2009. Above ground standing biomass and carbon storage in village bamboos in North East India. Biomass and Bioenergy 33: 1188-1196.

[30] Pilli R, Grassi G, Kurz WA, Smyth CE, Blujdea V .2013. Application of the CBM-CFS3 model to estimate Italy's forest carbon budget, 1995-2020. Ecological Modelling 266: 144-171.
[31] Stinson G, Kurz WA, Smyth CE, Neilson ET, Dymond CC, Metsaranta JM et al.2011. An inventorybased analysis of Canada's managed forest carbon dynamics, 1990 to 2008. Global Change Biology 17 (6): 2227-2244

[32] Thuille A, Buchmann N, Schulze ED .2000. Carbon stocks and soil respiration rates during deforestation, grassland use and subsequent Norway spruce afforestation in the Southern Alps, Italy. Tree Physiology 20 (13): 849-857.

[33] Vaidyanathana S, Jagdish K, Samba Kumar N, Dhanwatey H, Poonam D, Karanthe KU 2010. Patterns of tropical forest dynamics and human impacts: views from above and below the canopy. Biological Conservation 143: 2881-2890.

[34]UNFCCC .2005. Decision 16/CMP. 1 - Land use, land-use change and forestry. United Nations Convention on Climate Change. [online] URL: http://unfccc.int/resource/docs/2005/cmp 1/eng/08a03.pdf

[35] UNFCCC .2011. Decision 2/CMP. 7 Land use, landuse change and forestry. United Nations Convention on Climate Change. [online] URL: http://unfccc.int/methods/lulucf/items/4152.php

[36] UNFCCC .2013. KP LULUCF tables, submission 2013. Web site, United Nations Fremawork Convention on Climate Change, Bonn, Germany. [online] URL: http://unfccc.int/national_reports/ annex_i_ghg_inventories/national_inventories_s ubmissions/items/7383.php

[37] UNFCCC .2014. KP LULUCF tables, submission 2014. Web site, United Nations Fremawork Convention on Climate Change, Bonn, Germany. [online] URL: http://unfccc.int/national_reports/ annex_i_ghg_inventories/national_inventories_s ubmissions/items/7383.php

[38] Sustainable Development at Rio .1992. and Wildlife Conservation.

http://www.environmentalpollution.in/forestconservation/how-to-conserve-forest-resources-8steps/156

[39] Wilson BRSA, Daff JT .2003. Australia's state of the forests report. Department of Agriculture, Fisheries and Forestry, Govt. of Australia.

[40] Chhabra, A.; Palria, S. and Dadhwal, V. K. 2002. Growing Stock Based Forest Biomass Estimate for India. Biomass Bioenergy, 22: 187-194.

[41]Dadhwal VK and Nayak SR.1993. A Preliminary Estimate of Biogeochemical Cycle of Carbon for India. Sci. \& Cult. 59: 9-13. 
[42] Manhas RK, Negi JDS, Rajesh Kumar and Chauhan PS. 2006. Temporal Assessment of Grwoing Stock, Biomass and Carbon Stock of Indian Forests. Climate Change, 74: 191-221.

[43] Ravindranath NH, Somashekhar BS and Gadgil M 1997. Carbon flows in Indian forests. Climate Change, 1997: 35, 297-320.

[44] Ravindranath NH, Rajiv Kumar Chaturvedi and Murthy IK .2008. Forest conservation, afforestation and reforestation in India: Implications for forest carbon stocks. Current Science: 21695 (2): 216-222.

[45]Rawat VRS and Kishwan J .2008. Forest conservation- based, climate change-mitigation approach for India. International Forestry Review, 10(2): 269-280.

[46] Bowen HLM .1979. Environmental Chemistry of the Elements. Academic Press, London.

[47]Brown S and Lugo AE .1984. Biomass of Tropical Forests: A New Estimate Based on Forest Volumes. Science, 223: 1290-1293.
[48] Brown S, Gillespie AJR and Lugo AE .1991. Biomass of Tropical Forests of south and southeast Asia. Can. J. For. Res. 21: 111-117.

[49] Haripriya GS .2003. Carbon budget of the Indian forest ecosystem. Climate Change, 56: 291-319.

[50] Thomas SC and Martin AR .2012. Carbon content of tree tissues - a synthesis. Forests 3 (2), 332-352.

[51] Vilen T, MeyerJ, Thu rig E, Lindner $M$ and Green $T$ .2005. Improved regional and national level estimates of the carbon stock and stock change of tree biomass for six European countries (Deliverable 6.1). Improved national estimates of the carbon stock and stock change of the forest soils for six European countries (Deliverable 6.2). CarboInvent Project. European Forest Institute, p. 31.

[52]Zanchi G, Thiel D, Green T and Lindner M .2007. Forest area change and afforestation in Europe: critical analysis of available data and the relevance for international environmental policies. EFI Technical Report 24. European Forest Institute, p. 45.

\section{FIGURES}

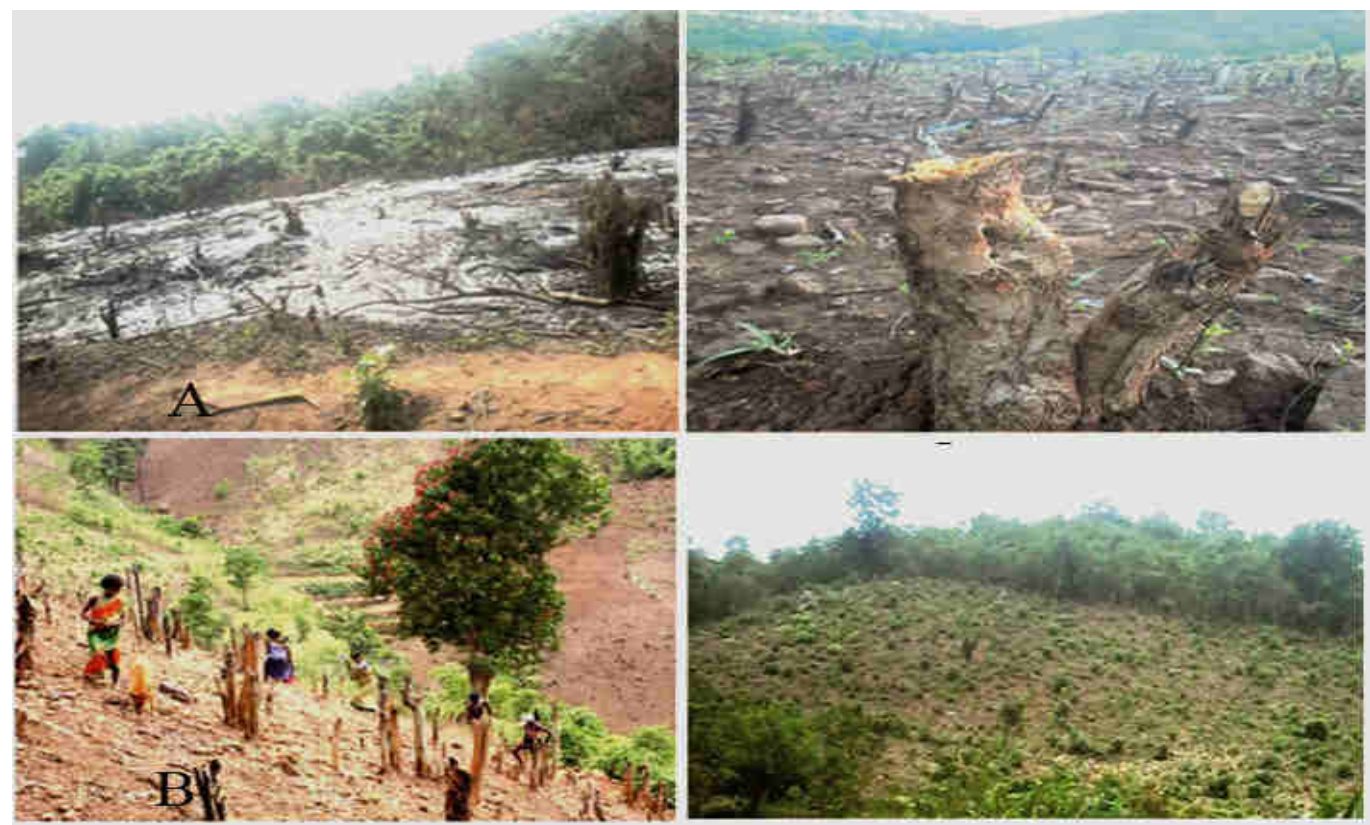

Fig.1: Tribal shifting of cultivation in Eastern Ghats leads to deforestation at Srikakulam, Vizayanagaram and Vishakhapatnam of Andhra Pradesh, India. 


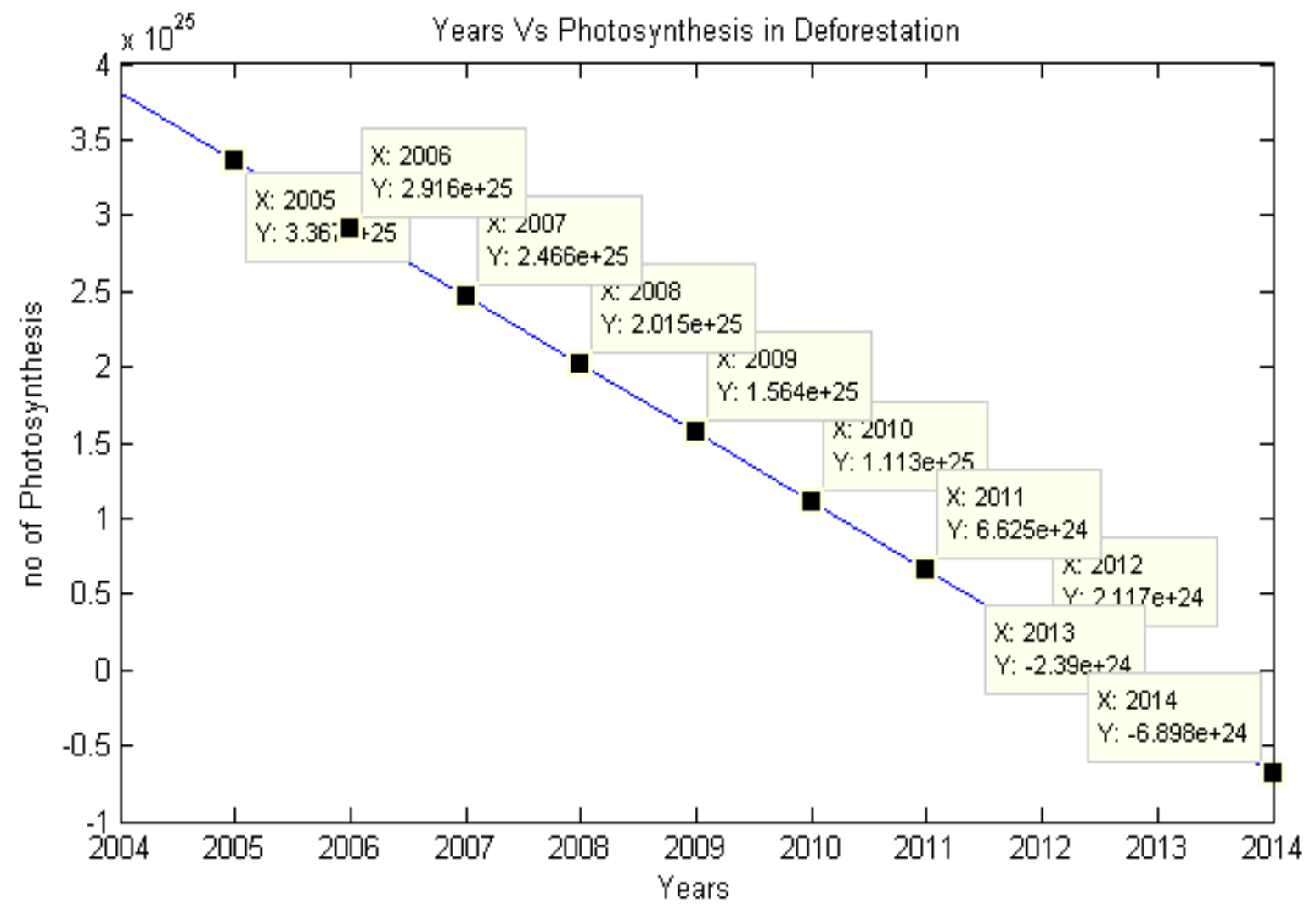

Fig. 2: Carbon sink decreasing order due to deforestation since $(2004-2014) \approx \approx-6.898 \times 10^{25} \mu \mathrm{mol} \mathrm{m}^{-2} \mathrm{~s}^{-1}$ i.e reduced amount of Photosynthesis reactions taking place.

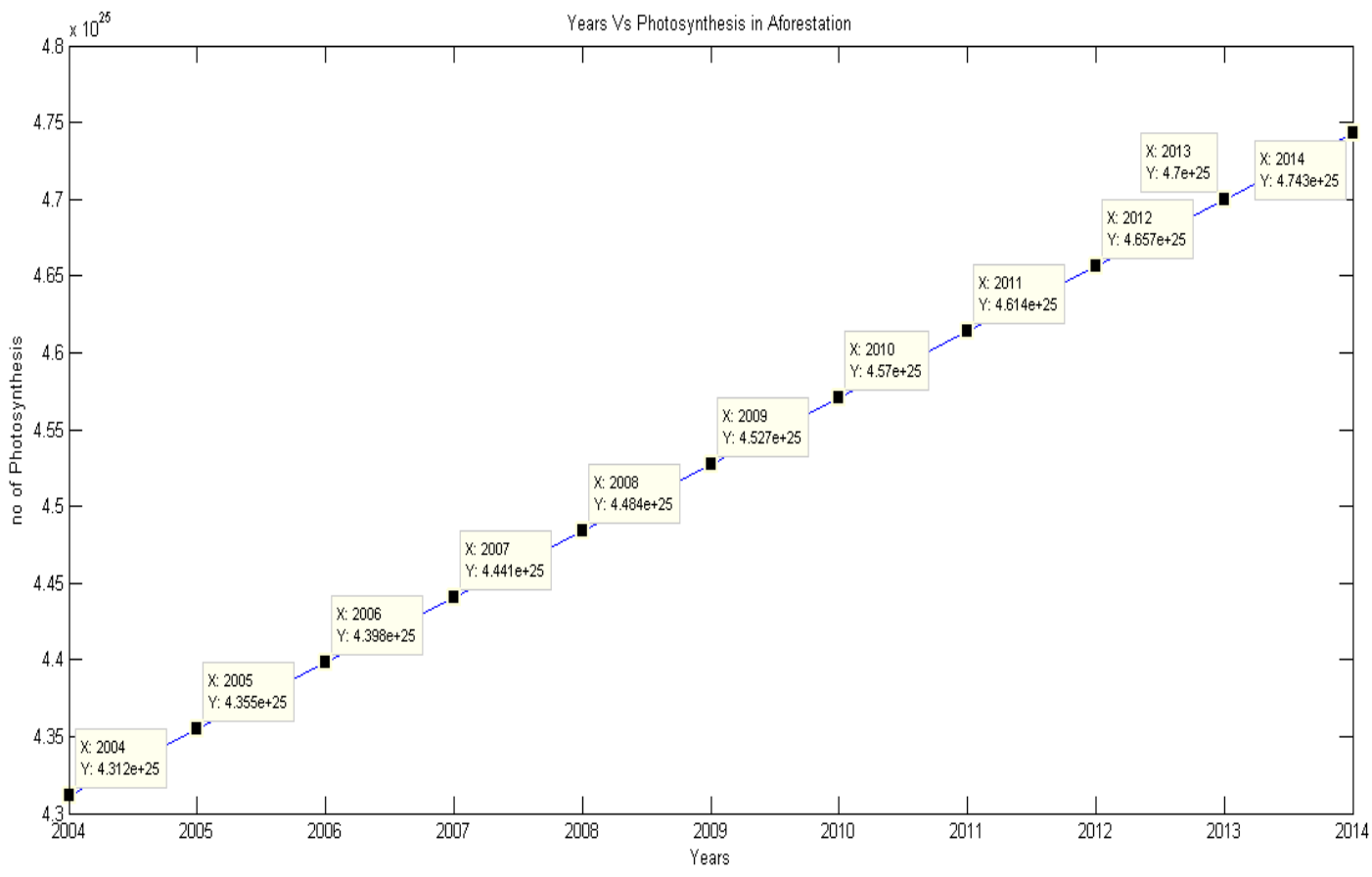

Fig. 3: Carbon sinks increasing order if Aforestation since $(2004-2014) \approx 4.743 \times 10^{25} \mu \mathrm{mol} \mathrm{m}^{-2} \mathrm{~s}^{-1}$ i.e more amount of Photosynthesis reaction taking place. 


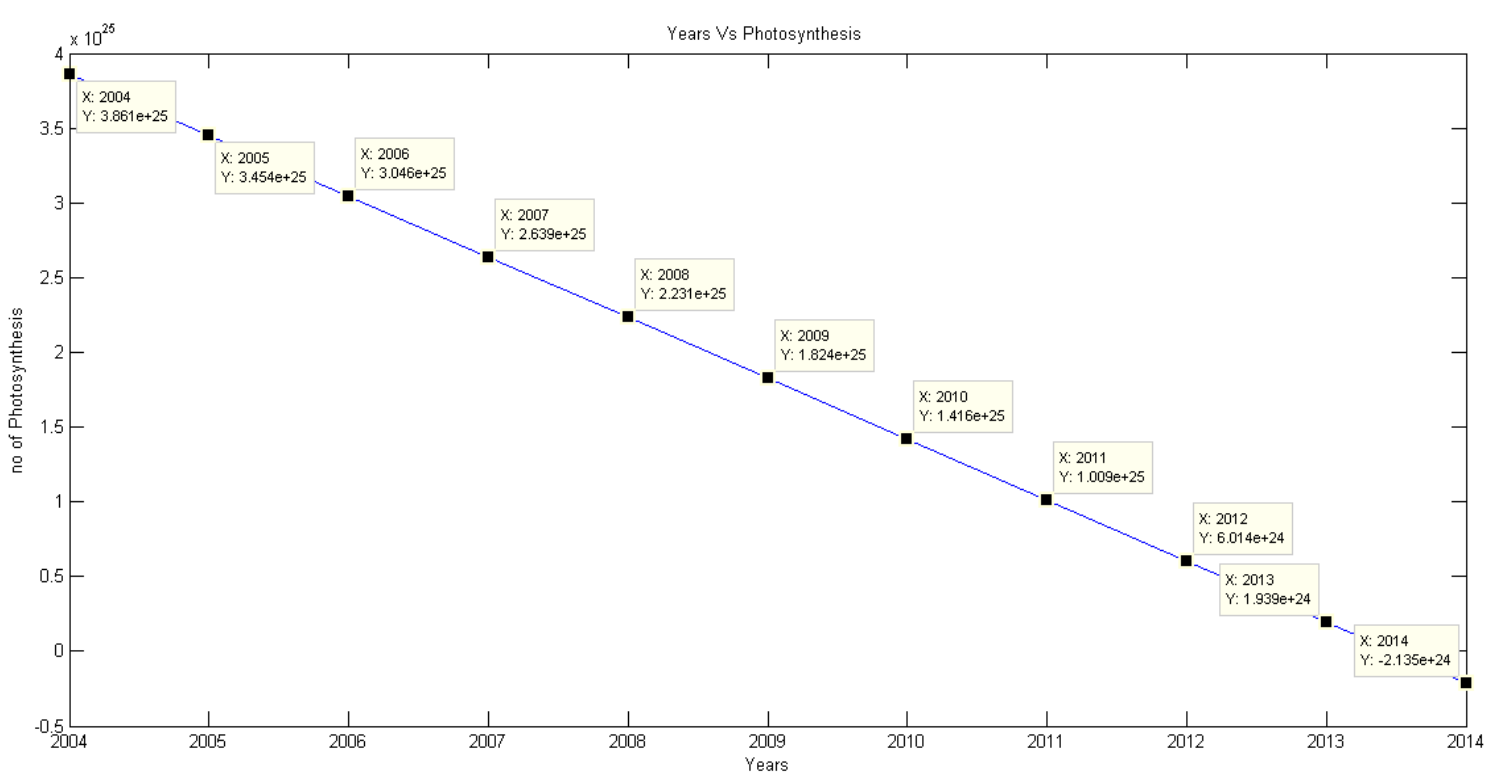

Fig. 4: Carbon sinks decreasing at combine effect of negative change and positive change $\approx-2.135 \times 10^{25} \mu \mathrm{mol} \mathrm{m}^{-2} \mathrm{~s}^{-1}$ (negative change: deforestation, shifting of cultivation and forest fire; positive change: Aforestation) i.e reduced amount of Photosynthesis reaction taking place.

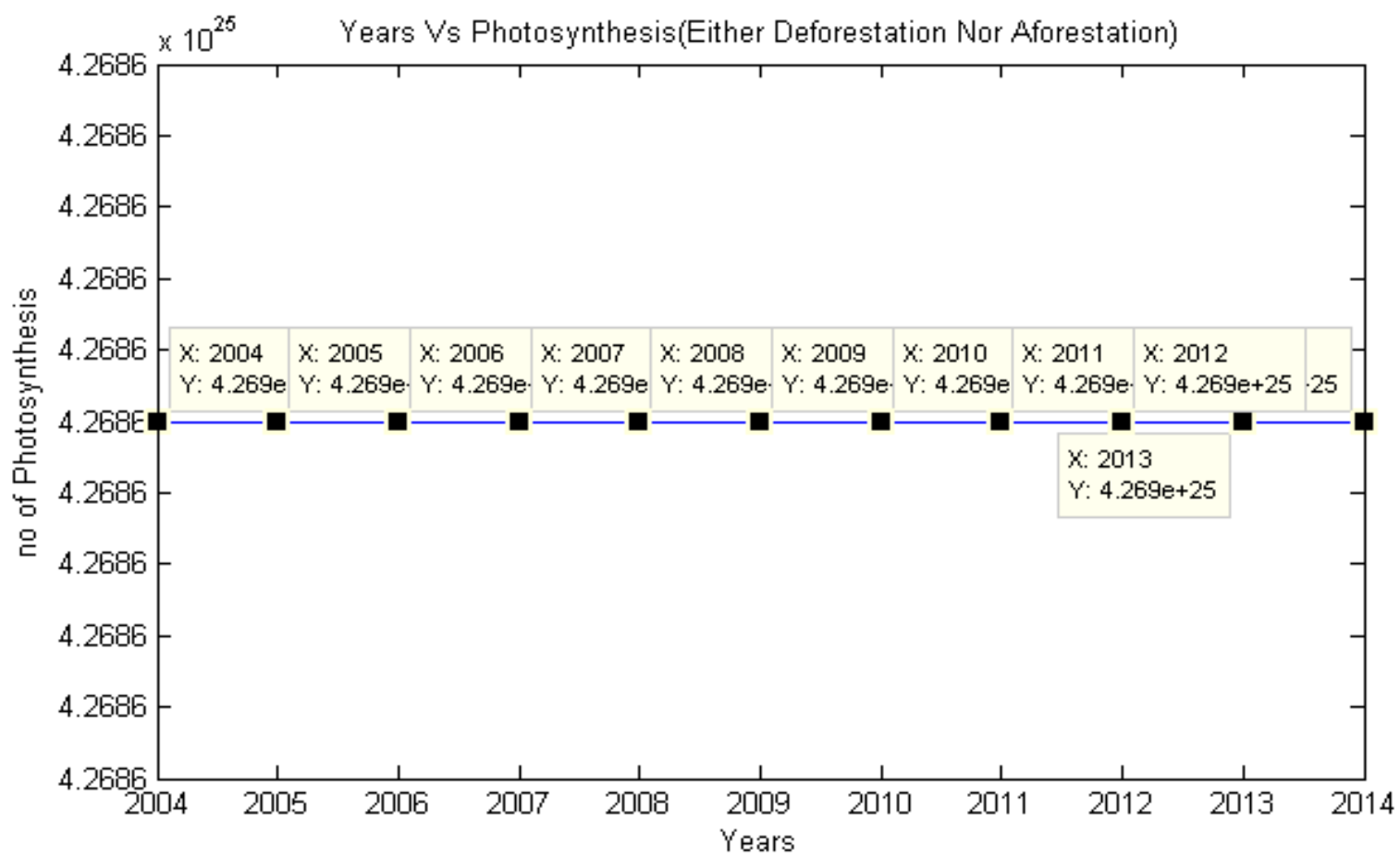

Fig. 5: Carbon sinks neutral since 2004-2014 either deforestation or Aforestation $\left(4.269 \times 10^{25} \mu \mathrm{mol} \mathrm{m}^{-2} \mathrm{~s}^{-1}\right)$ 


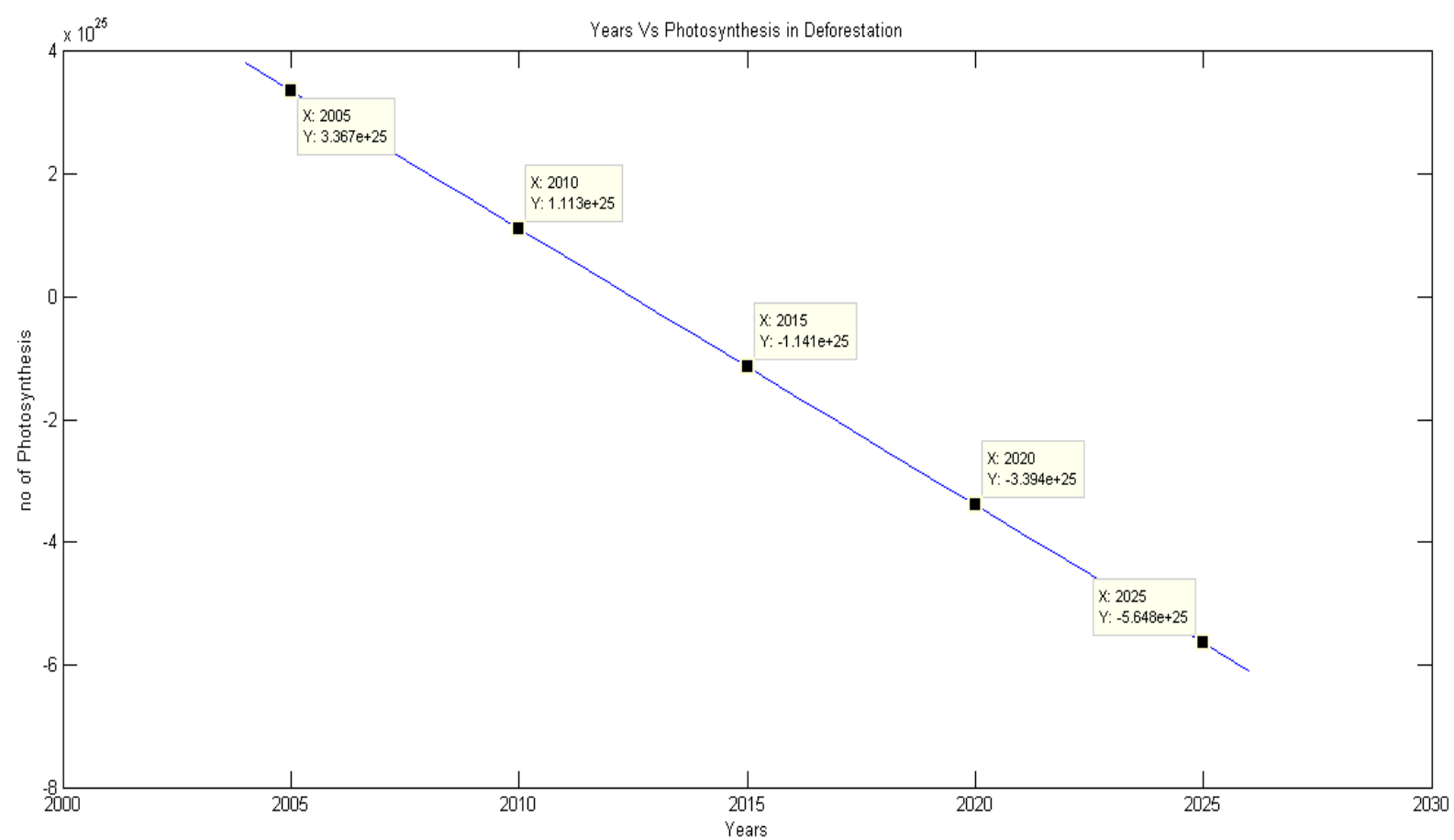

Fig: 6 : Carbon sink decreasing at deforestation (since 2005-2025) -5.648x10 $0^{25} \mathrm{~mol} \mathrm{~m}^{-2} \mathrm{~s}^{-1}$ i.e a reduced amount of Photosynthesis reactions taking place.

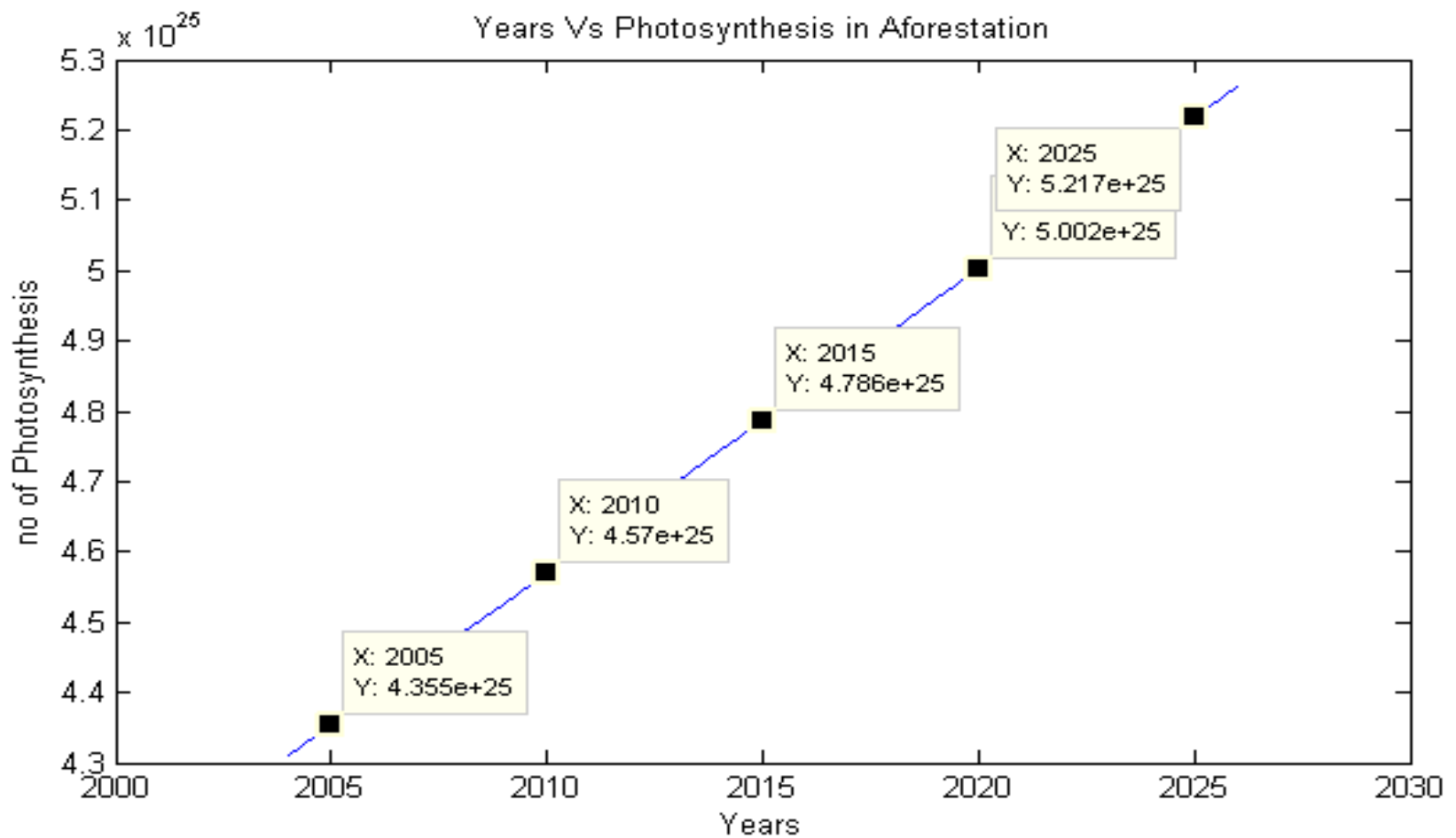

Fig: 7: Carbon sink increasing at Aforestation (since 2005-2025) 5.002x10 $0^{25} \mu \mathrm{mol} \mathrm{m} \mathrm{m}^{-1}$ i.e additional amount of Photosynthesis reactions taking place. 


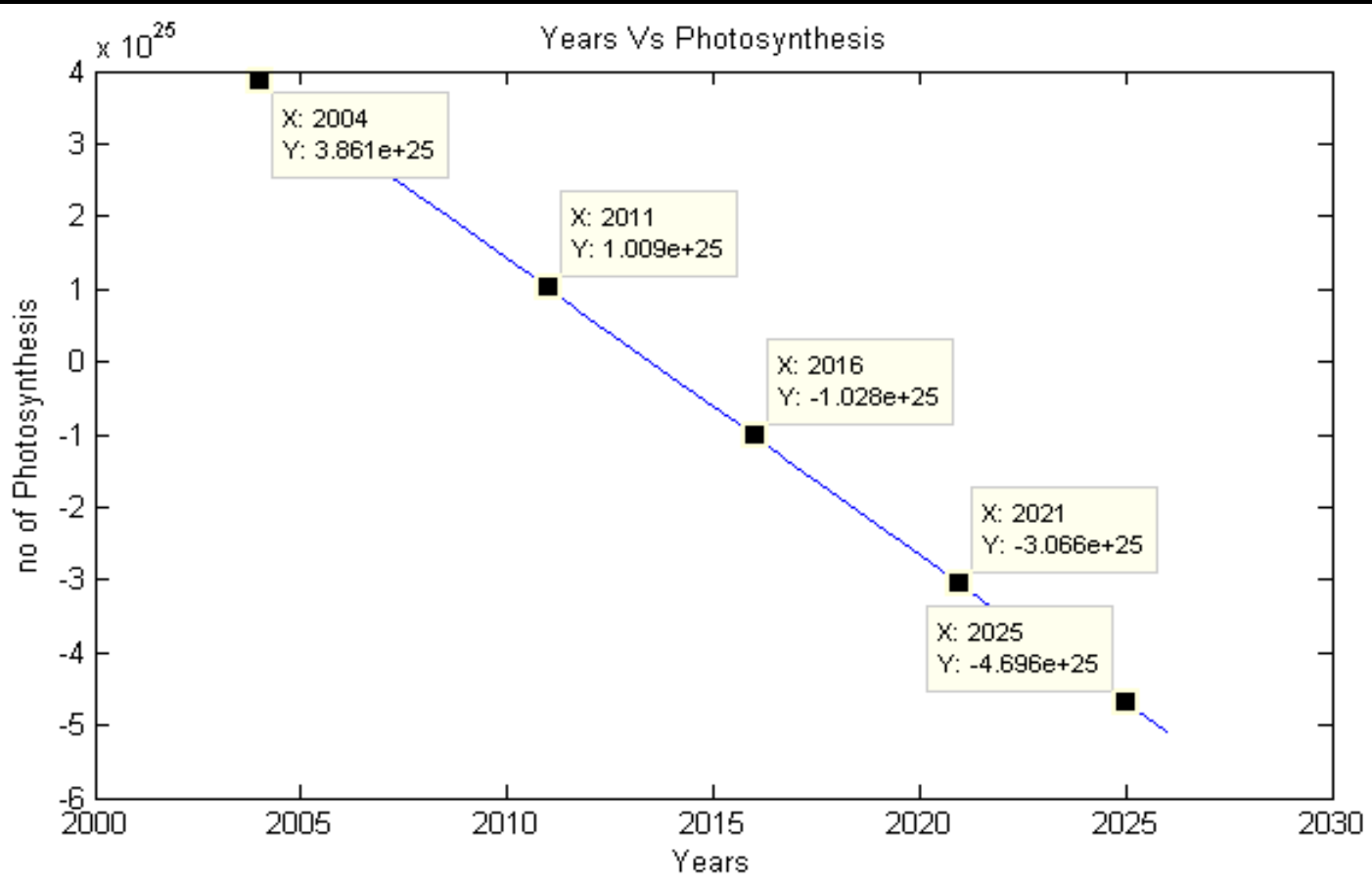

Fig.8: Carbon sinks decreasing since 2005-2025 at combine effect of negative change and positive change $\approx-4.696 \times 10^{25} \mu \mathrm{mol} \mathrm{m}^{-}$ ${ }^{2} s^{-1}$ (negative change: deforestation, shifting of cultivation and forest fire; positive change: Aforestation) i.e reduced amount of Photosynthesis reaction taking place.

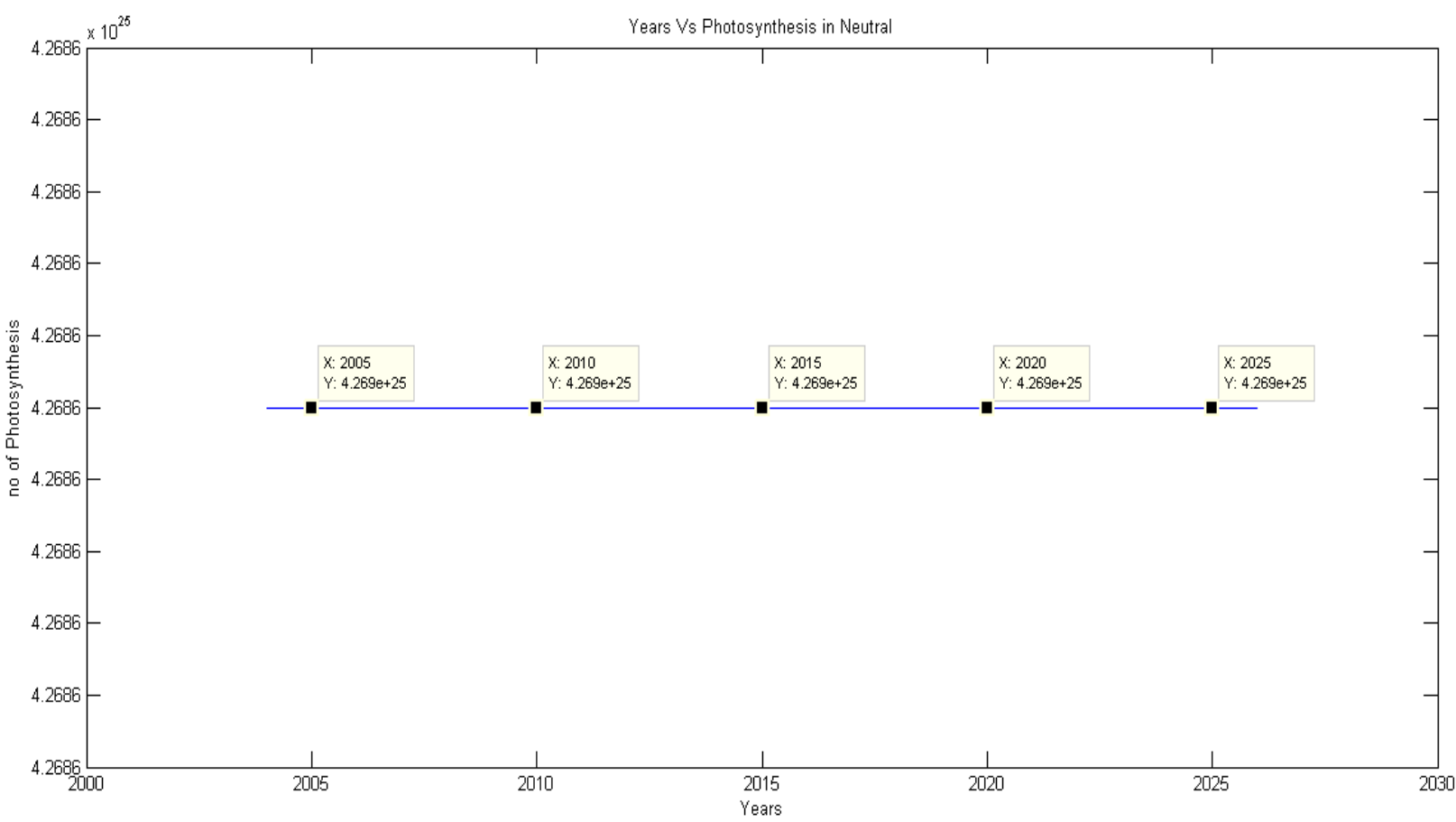

Fig. 9 : Carbon sinks neutral since 2005-2030 either deforestation or Aforestation (4.269x10 $0^{25} \mu \mathrm{mol} \mathrm{m}^{-2} \mathrm{~s}^{-1}$ ) 